\title{
Surveying support for child and youth political participation in Australia and New Zealand
}

\section{Louise Gwenneth Phillips, Jenny Ritchie \& Francisco Perales}

To cite this article: Louise Gwenneth Phillips, Jenny Ritchie \& Francisco Perales (2019) Surveying support for child and youth political participation in Australia and New Zealand, Citizenship Studies, 23:5, 460-485, DOI: 10.1080/13621025.2019.1620687

To link to this article: https://doi.org/10.1080/13621025.2019.1620687

\section{Published online: 30 May 2019.}

6 Submit your article to this journal

III Article views: 82

View Crossmark data $₫$ 


\title{
Surveying support for child and youth political participation in Australia and New Zealand
}

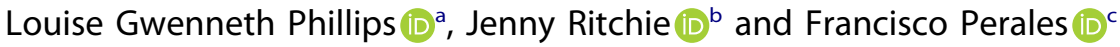

aSchool of Education, The University of Queensland, Brisbane, Australia; 'bSchool of Education, Victoria University of Wellington, Wellington, New Zealand; Institute for Social Science Research, University of Queensland, Brisbane, Australia

\begin{abstract}
Recent decades have witnessed increased empirical and policy interest in children's citizenship, particularly since the ratification of the United Nations Declaration of Children's Rights. However, support for children's active citizenship is often hindered by the pervasiveness of discourses that characterise children as innocent, developing, and free from responsibility. Public and governmental decision-making largely excludes children's consultation and contributions, often determined by age alone. To quantifiably assess the amount of public support for children's political participation, we commissioned a Likert scale survey question on degrees of support for children and youth (across four age groups between 3 and 18 year olds) having the opportunity to influence government decisions, in the Australian and New Zealand 2016 versions of the International Social Survey Programme (ISSP). Analysis of responses to this question in relation to demographic survey data indicate variation in preferences for different age groups, and that age, gender, and political party preference of respondents were variables of significance for both nations. These variables point to potential predictors of attitudes toward political participation of children and youth which have relevance for policymakers and educators in relation to provision of programmes that will increase the engagement of children and youth in government decision-making.
\end{abstract}

\section{ARTICLE HISTORY}

Received 9 September 2018

Accepted 6 February 2019

\section{KEYWORDS}

Children; survey research; cross-national research; International Social Survey Programme; political participation

\section{Introduction}

The default position in social and political theory is to consider children as learner citizens in waiting or to disregard children altogether (e.g. see Qvortrup 2003; BühlerNiederberger 2010). The trend in western modern and neo-liberal societies is to shield or protect children from participation in the 'outside world' (de Winter 1997). Such perceptions of children stem from Enlightenment thinking. This is evidenced in the work of scholars such as Rousseau, Locke and Goethe, who argued for children to 'be exempted from adult duties and responsibilities for a prolonged period of time' (de Winter 1997, 48) to better focus on their education. Attempts to promote civic learning and action are often aimed at secondary school students, and are largely focused on the maintenance of social and political institutions and the integration of youth into the 
political system (Flanagan 2012). As Milne $(2013,27)$ posits: 'Children and youth are almost entirely without genuine political and economic influence', and are in effect 'equated with the stateless, nationality less, criminal and mentally ill'. Public and governmental decisions largely exclude children's consultation and contribution, yet signatories to the United Nation's Convention on the Rights of the Child (UNCRC) (1989) have state responsibilities to enact the articles that enshrine children's political rights, such as will formation (Article 13), to take part in the conduct of affairs in relation to matters affecting them (Article 12), peaceful assembly and freedom of association with others (Article 15). These rights, however, are less readily embedded in national law and social policy, even in democratic societies. For example, the last UN Committee on the Rights of the Child concluding observations report on Australia (2012) noted that there is no national children's rights act that gives full and direct effect to the UNCRC, and for New Zealand there was no 'legislative duty to do so' (Lundy et al. 2012, 84). Social and cultural rights for children are more readily accepted and embedded in state law (Lundy et al. 2012), such as the social rights to education (Article 28 of the UNCRC), and health care (Article 24) and the cultural rights to practice their own language and culture (Article 30) and to take part in cultural life (Article 31). However, children's civic engagement is held to be essential for achieving international development goals (Milne 2013, 216), such as the UN Sustainable Development Goals (United Nations n.d.).

This disjuncture between recognised rights and legislation and policies poses questions about a related important consideration: the extent of public support for enacting children's political rights as citizens. Many scholars (e.g. Phillips 2010; Prout, 2002; Stasiulus, 2002) have noted that adult attitudes towards children block and or limit scope for enactment of children's political rights. Most surveying that happens in this domain focuses on youth and their political participation practices or civic engagement, such as Flanagan and Levine's (2010) surveying of youth civic participation in the USA from the 1950s to the 2000s; Saha, Print, and Edwards' (2005) Australian survey of 4,855 senior secondary school students on voting and political actions; and O'Connor's (2011) study of 1,700 culturally diverse young New Zealanders' community participation and well-being. We were unable to locate any quantitative studies of political participation of primary or early childhood children, nor of quantifiable indication of societal support for political participation of children or youth. Most research on younger generations' political participation focusses on youth (14-18 year olds) or young people (18-24 year olds). In recent decades, the research focus has shifted from interest in youth political socialisation to civic engagement to be more inclusive of the diverse ways people can participate in the public sphere (Torney-Purta and Amadeo 2013). In a commissioned review of empirical research on civic learning and action, Flanagan (2012) found that almost no studies focus on elementary age children, let alone on early childhood. This, Flanagan argues, 'may reflect the challenges of conceptualising civic learning and civic action in this age group' (p. 13). Our interest is specifically on political participation, as defined as having influence on government and Phillips and Ritchie's research particularly focuses on young children's civic engagement in early childhood education settings. As sociologists, we are interested in how the polis (a public sphere where members engage in activities of common interest [Turner 1993]) may be more intergenerationally inclusive in relation to interest 
sharing, decision-making and collective action, by both adults and children enacting the political rights to freedom of expression, opinion and participation in the conduct of public affairs.

Given the scarcity of robust survey data that could be used to gauge the degree of support for children's political participation, we commissioned a question within the Australian and New Zealand 2016 iterations of the International Social Survey Programme. A random sample of electoral enrollees completed the survey, which included our question on their views about children, and youth (3-18 year olds) exercising their political rights, that is, having opportunities to influence government decisions. This article summarises and discusses these results for Australia and New Zealand. First, we provide an overview of dominant adult perceptions of children, youth and correlated political participation. Next, we provide some background on the International Social Survey Programme and its Australian and New Zealand arms. This is followed by explanations of the methodology used to analyse the data. We then discuss the results identifying demographic patterns and predictors of support for children exercising their political rights, and conclude with implications and considerations for how children's political engagement and influence may be welcomed and created. This work adds to previous discussions initiated by Cohen (2005) pertaining to children and childhood's construction in politics, in which she asserts that 'Liberal democracies owe children a more carefully defined and judiciously governed political status that acknowledges their needs alongside their weaknesses and vulnerabilities' ( $\mathrm{p}$. 236). By analysing the socio-demographic predictors of support for children's and youth's political participation, we generate novel insights about which population groups welcome these practices.

\section{Adult perceptions of children's political participation}

Adult perceptions of children are diverse and contextually located, yet some historically, socially and culturally constructed conceptualisations dominate. The following discusses these patterns of adult perceptions of children with regard to children's political participation.

The legacy of John Locke's (1690/1959) tabula rasa thesis is recognised to have conceptualised children as immanent, that is becoming or latent reasoners with reason being understood to be acquired with age. Based on this view, adults have a higher status and exercise control over children by virtue of age, experience, and knowledge. A view of children as immanent has influenced social policy in western societies, which has largely defined children and youth as 'incompetents' (Morrow 1994, 51). From this position, children are removed from responsibility in that they do not vote or work. They are also seen as dependent, relying on adults for care, protection and education. When viewed as immanent, children's participation as citizens are impacted through their exclusion from various social practices and responsibilities. Standards that do not consider individual consideration of competence (e.g. the requirement to be 18 to be eligible to vote in Australia and New Zealand) enforce many of these exclusions. A theoretical model of children as immanent views children as not old or knowledgeable enough to politically participate. 
Another enlightenment scholar, Jacques Rousseau (1762/2007) is understood to have framed the perception of children as innocent - angelic, uncorrupted by the world, and naturally good. To Rousseau, children were born with a natural goodness as expressed in his treatise on education, Emile: 'Everything is good as it leaves the hands of the Author of things' (p. 37). Based on this understanding, adults 'generate a desire to shelter children from the corrupt surrounding world' (Dahlberg, Moss, \& Pence, 1999, 45). Adults maintain the natural goodness of children by protecting them from violence and corruption through surveillance, limitation and regulation. This construct has privileged the position of adults to withhold knowledge in the name of protection and reinforces a notion of the child as ignorant or immanent, in turn creating children who feel vulnerable and disempowered (e.g. see Cannella and Viruru 2004). Such a perspective limits children's engagement with real-world issues and active citizenship participation on these issues. As Dahlberg et al. (1999) claimed, by protecting children from the world in which they exist, adults do not respect the rights and capabilities of children to seriously engage in the world.

A perception of children as naturally developing was largely shaped by empirical research conducted by Piaget (e.g. 1952), involving his own children. This model brings together the naturalness of children (Rousseau 1762/2007) and the tabula rasa thesis (Locke 1690/1959) to form the idea of inevitable maturation. Piaget determined that there is a developmental pathway to intelligence that positions adults as competent and supreme, and children as incomplete, incompetent, and irrational because of their developing status (James, Jencks, and Prout 1998). Learning and participation are understood in this theoretical model as being guided and limited by universally accepted stages of development. This perception of children emphasises individualism and masks the extent to which children are capable and take responsibility in their lives, because children are seen to be in preparation for future participation, not agentic in the present. Adults are positioned as competent and capable beings who understand, translate and interpret children's comments and actions (Waksler 1991). This view of children is based on a deficit model, which positions children as needing guidance. According to Lansdown (2005), a deficit model makes much of children's agency invisible. This future orientation limits the possibilities for young children's active citizenship within the wider community in the here and now, to being determined by adults in defined developmental stages. A view of children as developing shaped the qualification of the UNCRC articles 5 and 14 defining parental guidance of children exercising their rights 'in a manner consistent with the evolving capacities of the child' (United Nations General Assembly 1989).

A perception of children as uncontrolled and impulsive was shaped by psychoanalytic theorists, such as Freud (1923), framing the child as unconscious - unthinking in their actions. Children viewed this way are highly ego-focused; consciousness and therefore consideration of others is minimal. Emphasis is on children's unconscious instincts in their learning and participation. As with the perception of children as naturally developing, recognition of the unconscious behaviours of children also views them as becoming, with the emphasis on becoming rational (James, Jencks, and Prout 1998). This view of children as impulsive and/or irrational has been identified by Arneil (2002), Kulnych (2001), and Stasiulis (2002) as an argument used against children's recognition and participation as citizens. 
Each of the above four perceptions view children as citizens of the future. Such views continue to shape both social and educational practices with children (James, Jencks, and Prout 1998). In more recent times, following the influences of progressivism and critical theory, perceptions of children have expanded to challenge the universalistic and future-oriented perceptions of children discussed above. The UNCRC and sociology of childhood (e.g. Corsaro 1997; James, Jencks, and Prout 1998) are key catalysts for perceptions of children as rights holders and social actors of today. The acceptance of the UNCRC was made possible through modern understandings defining childhood as separate from adulthood, with marked distinctions in expected behaviours, roles, and responsibilities (Archard 2015).

The UNCRC came into fruition through recognition of children as a minority group, positioned as powerless, and disadvantaged (Oakley 1994). Children viewed as a minority are seen to be deserving of the same rights as adults, yet they rarely receive these rights. Children's minority group status is presented through adults making decisions for them based on the claim that it is 'in their best interests' as per the qualifiers sprinkled throughout the UNCRC (Coady 1996; Oakley). Adults, who view children as a minority group, act as advocates for (or ideally with) children by arguing that children should have the same rights to citizenship participation as adults. Critical theorists such as Giroux (1983) challenged the social demarcation of childhood as justifying ongoing adult domination of children. The claim by Cannella and Viruru (2004) that children are colonised by adult manipulation also highlights this perspective. If children are viewed as a minority group their citizenship participation is recognised as limited and constrained by social constructions. Such a view, groups children together, proposing uniformity while ignoring variations, in the same way cross-cultural critics of the feminist movement saw claims for women's rights (James, Jencks, and Prout 1998). A view of children as a minority group presents a strong case for including children's political participation; however, social and cultural variations may be glossed over by grouping all children together.

Another way of viewing children is as political beings. A notion of children as political, acknowledges children as agentic. A view of children as political particularly emphasises access and participation in the public sphere. Our perception of children as political is not particularly concerned with government and party politics that large studies such as those conducted by Hess and Torney (1967/2006) in the US in the late 1960s and Connell (1971) in Australia examined. These political socialisation studies interviewed children with a view of them becoming political on matters such as political party affiliations, government structure and voting. In contrast to these studies, we see children as political now. Kulynych (2001) proposed children's political identities can be supported through children's access to the public sphere and acceptance of their expressions of resistant and disorderly forms of participation. By 'involving children from a very early age in the organisation of the world in which they live, their repertoire of behavioural capabilities grows' (de Winter 1997, 163). A view of children as political welcomes their participation as active citizens in the public and community spheres. Community acceptance of children's political rights can be fuelled by the demonstration of children's capacity as participatory citizens (Lister 2008). Many scholars (e.g. Torney-Porta \& Amadeo, 2013) of civic education hope that the evidence of their studies that demonstrate children and youth active civic engagement and knowledge 
will broaden community acceptance of children's political rights, countering negative perceptions of youth as apathetic, disengaged and unreliable. It is argued that such findings are 'an important lesson for adults (parents, teachers, and politicians), who may underestimate what most youth are capable of as citizens and members of their communities' (Torney-Porta \& Amadeo, 108), and challenge long-standing perceptions of children as immanent, innocent, developing and impulsive.

Children are also perceived as socially constructed, which acknowledges diversity in relation to the social, political, historical and moral context of each child. The idea of children as socially constructed draws from social constructionism. Social constructionist research about children suspends beliefs of taken-for-granted meanings about children (James, Jencks, and Prout 1998). A universalistic view of children is not accepted. Instead, plurality and diversity are welcomed. An understanding of children as socially constructed enables recognition of multiple discourses contributing to a collective appreciation of the condition of childhood. Childhood is understood as historically contingent and unfixed. Adults question, analyse, and reflect on the influence of social constructions of children's learning and participation. Such a view of children enables identification of social structures that shape the possibilities for children's political participation.

The absence of empirical data about adults' views of youth participation in government decision-making allows the perpetuation of a trope that classifies youth as disinterested in democratic engagement. According to Collin (2015): 'Narrow conceptions of politics and limited forums for engaging with young people's views typically present young people as apathetic, frivolous or alienated' (97). The adults in a Tucson, USA study were often surprised by the level of youth participation due to the pervasiveness of views that characterised youth as 'the problem,' and other negative stereotypes leading to low expectations, along with assumptions regarding adult privilege contributing to unequal relationships (Harris et al. 2016). Briggs (2017) reports that a range of research 'has discovered that young people are not apathetic but that they are uninterested and disillusioned with mainstream politics' (160-161). Since adults, many of whom are influenced by these negative stereotypes, are in charge of institutional mechanisms, it is hardly surprising that young people do not feel attracted to participate, since they 'do not feel they are working for them' (a researcher stakeholder interviewee, as cited in Cammaerts et al. 2016, 92). Neo-liberal social and economic policies in recent decades have increased diversity and disparities amongst young people (Cammaerts et al. 2016), compounding the negative community perceptions. We agree with the proposition regarding children and youth engagement in government decision-making, that intervention is required to challenge these tropes that characterise youth as disengaged and apathetic, in order to address what will otherwise be a self-fulfilling prophecy.

Collectively, these perceptions of children and youth continue to circulate and influence adult thinking about children and youth's political inclusion and participation. In this context, this study constitutes a novel attempt to identify the degree of public support for children and youth's political participation, and the sociodemographic indicators that predict such support. In doing so, we fill an important gap in scholastic knowledge, as it is recognised that 'there is a general lack of data on children's participation with available data mainly focused on the 18-25 age range' 
(Australian Research Alliance for Children and Youth, 2013, 22) and in New Zealand research on "young people's experiences of participation are often piecemeal, polarised in representation, regulated by adults and limited to certain spatial domains" (Wood 2011, 40). To enable children's and youth political participation, Lister (2007, 2008) suggested that adults view children and youth as citizens so that they experience being treated respectfully as citizens, come to see themselves as citizens, and participate actively as citizens.

\section{The International Social Survey Programme}

Given the social and theoretical trends of excluding or reducing children's political participation, we wondered to what quantifiable degree there was public support for children's political participation and if such had previously been measured. In 2012, the UN Interagency Network on Youth Development surveyed 13,000 young people across 186 countries, with the majority highlighting that the main challenges for youth (15-24 year olds) were limited opportunities for effective participation in decisionmaking processes (United Nations Development Programme, n.d). While evidence of children's political exclusion is clear, the degree of public support for children's political participation - to the best of our knowledge - has not been surveyed. Policymakers respond, to some extent, to the policy preferences of citizens (e.g. see Burstein 1998), so we therefore sought to survey public opinion for children's political participation as a potential means to influence social policy change for children's political participation.

We then looked to the International Social Survey Programme (ISSP) as a vehicle to survey public opinion in Australia and New Zealand with regard to children and youth being able to influence government decisions, and the role of different sociodemographic characteristics in increasing or decreasing such support. Established in 1984, the ISSP is a cross-national collaboration programme of currently 45 member countries that annually surveys public opinion on different social science topics each year. In 2016, we commissioned a question to the Australian Survey of Social Attitudes (AuSSA) and the International Social Survey Programme (ISSP) for New Zealand (ISSPNZ), when the focus that year was Role of Government.

The AuSSA is managed by the Australian Consortium for Social and Political Research Incorporated, and the data were collected via a self-completion mail questionnaire. To construct the sample, 5,000 citizens were randomly selected from the Australian Electoral Roll, of which 1,435 returned a completed survey. ${ }^{1}$ The ISSPNZ is also a self-completion postal survey with an online completion option and is managed by the Centre of Methods and Policy Application in the Social Sciences (COMPASS) at the University of Auckland, with collaborators from the University of Auckland Department of Sociology (Wu and Milne 2017). A stratified random sampling approach was employed to ensure demographic representation across nine categories, including Māori and non-Māori, Auckland and non-Auckland residents, women and men, and different age groups. Of the 4,075 surveys sent out, 1,350 individuals returned a completed questionnaire. After list wise deletion of cases with missing data on model variables, our analytic samples are 1,146 in the 2016 AuSSA and 1,264 in the 2016 ISSPNZ. Because participation rates were low in both survey instruments $(28.7 \%$ for Australia and $33.1 \%$ for New Zealand) and likely to be differentially distributed across 
demographic groups, in the analyses performed in this study we calibrate the data using the response weights provided by the data collectors. Doing so reduces the risk of nonresponse bias and enables the use of inferential statistics.

\section{Survey measures}

In both the 2016 AuSSA and the 2016 ISSPNZ, the commissioned question we included asked respondents: 'How strongly do you agree or disagree with children and youth (3-18 year olds) having opportunities to influence government decisions (e.g. inclusion in public consultations and inquiries, city councils' children's and youth policies, youth parliamentary representatives, councils)?'. Respondents were asked to select their degree of agreement on a 5-point Likert scale ranging from 'strongly disagree' (1) to 'strongly agree' (5), and to provide separate responses for different age groups: children aged 3 to 5 years, 6 to 10 years, 11 to 14 years, and 15 to 18 years. This was the first time since the inception of the ISSP in 1983 that a question that positions children as citizens has been included in the survey. Previous iterations of the ISSP have referred to children as dependents in health, care and education questions only. ${ }^{2}$ Asking such a question in the ISSP challenges dominant social constructions of children as dependents by including children as citizens in a research programme that claims to be a leading example of globalisation in social-science research and professes to follow principles of equality and inclusiveness (Smith 2010, 2015).

Because this 5-point Likert scale is an ordered variable, we modelled it using ordered logistic regression. We consider a range of socio-demographic variables as potential predictors. These include dummy variables capturing respondents' self-reported gender, age group, education, place of birth, identified as Aboriginal or Torres Strait Islander (Australia) or Māori (New Zealand), identified with a religion, had children age 0-17 in the household, and income level. In additional analyses, we also consider the role of political party preferences, specified as a set of dummy variables capturing for which major party the respondent voted in the last general election (Australia: Labor Party/ The Coalition/The Greens/Other party; New Zealand: Labour party/National party/ New Zealand First/Other party).

Descriptive statistics for all analytic variables are shown in Table 1 (Australia) and Table 2 (New Zealand).

\section{Results}

In this section, we present the results of our empirical analyses of the 2016 AuSSA and ISSPNZ data. We first report on the distribution of support for children and youth having opportunities to influence government decisions using descriptive statistics, and then report the results of multivariate ordered logistic regression models examining the socio-demographic factors associated with higher and lower levels of support.

\section{Descriptive patterns}

Figures 1 and 2 show the distribution of the Likert-scale support variables for each age group, for Australia and New Zealand, respectively. In Australia, 7.9\% of respondents 
Table 1. Sample descriptive statistics, Australia.

\begin{tabular}{|c|c|c|c|c|}
\hline & Mean/\% & SD & Min. & Max. \\
\hline \multicolumn{5}{|c|}{ Support for children influencing government decisions } \\
\hline \multicolumn{5}{|c|}{ Likert scale } \\
\hline Children age 3-5 & 1.91 & 1.00 & 1 & 5 \\
\hline Children age 6-10 & 2.23 & 1.10 & 1 & 5 \\
\hline Children age $11-14$ & 2.88 & 1.22 & 1 & 5 \\
\hline Children age $15-18$ & 3.77 & 1.15 & 1 & 5 \\
\hline \multicolumn{5}{|l|}{ Explanatory variables } \\
\hline \multicolumn{5}{|l|}{ Gender } \\
\hline Male & $49.89 \%$ & & 0 & 1 \\
\hline Female & $50.11 \%$ & & 0 & 1 \\
\hline \multicolumn{5}{|l|}{ Age group } \\
\hline $18-30$ years & $23.23 \%$ & & 0 & 1 \\
\hline $31-45$ years & $21.41 \%$ & & 0 & 1 \\
\hline $46-60$ years & $28.94 \%$ & & 0 & 1 \\
\hline Over 60 years & $26.41 \%$ & & 0 & 1 \\
\hline \multicolumn{5}{|l|}{ Education } \\
\hline Degree or higher & $22.49 \%$ & & 0 & 1 \\
\hline Professional qualification & $34.31 \%$ & & 0 & 1 \\
\hline School year 12 & $18.98 \%$ & & 0 & 1 \\
\hline Below school year 12 & $24.22 \%$ & & 0 & 1 \\
\hline \multicolumn{5}{|l|}{ Country of birth } \\
\hline Not Australian born & $25.49 \%$ & & 0 & 1 \\
\hline Australian born & $74.51 \%$ & & 0 & 1 \\
\hline \multicolumn{5}{|l|}{ Indigenous status } \\
\hline Not Indigenous & $97.50 \%$ & & 0 & 1 \\
\hline Indigenous & $2.50 \%$ & & 0 & 1 \\
\hline \multicolumn{5}{|l|}{ Religious identification } \\
\hline No religion & $41.12 \%$ & & 0 & 1 \\
\hline Has a religion & $57.18 \%$ & & 0 & 1 \\
\hline No religion info & $1.70 \%$ & & 0 & 1 \\
\hline \multicolumn{5}{|l|}{ Children in the household } \\
\hline No & $67.28 \%$ & & 0 & 1 \\
\hline Yes & $32.72 \%$ & & 0 & 1 \\
\hline \multicolumn{5}{|l|}{ Income levels } \\
\hline Bottom quartile & $25.00 \%$ & & 0 & 1 \\
\hline Middle two quartiles & $31.74 \%$ & & 0 & 1 \\
\hline Top quartile & $15.97 \%$ & & 0 & 1 \\
\hline No income information & $27.29 \%$ & & 0 & 1 \\
\hline \multicolumn{5}{|l|}{ Political party preference } \\
\hline Labor Party & $28.52 \%$ & & 0 & 1 \\
\hline Coalition & $39.41 \%$ & & 0 & 1 \\
\hline Greens & $12.58 \%$ & & 0 & 1 \\
\hline Other party & $11.14 \%$ & & 0 & 1 \\
\hline No vote or no information & $8.35 \%$ & & 0 & 1 \\
\hline
\end{tabular}

Notes: AuSSA data, 2016 (weighted for differential non-response). $n=1,146$.

agreed or strongly agreed that children age 3-5 should have opportunities to influence Government decisions, compared to $15.1 \%$ for children age $6-10$ years, $38.3 \%$ for children age 11-14 years, and 71\% for children age 15-18 years. In New Zealand, the percentage of respondents agreeing or strongly agreeing with this notion was $6.6 \%$ for children aged $3-5,9.7 \%$ for children aged $6-10,28.4 \%$ for children aged $11-14$, and $63.5 \%$ for children aged 15-18. Therefore, across both countries comparatively few respondents agreed that young children should have opportunities to influence government decisions, rates of agreement increased linearly with age, and most respondents held the view that adolescents age 15-18 should have the means to do so. Support rates were higher in the Australian than the New Zealand sample, particularly for questions asking about older children. 
Table 2. Sample descriptive statistics, New Zealand.

\begin{tabular}{|c|c|c|c|c|}
\hline & Mean/\% & SD & Min. & Max. \\
\hline \multicolumn{5}{|c|}{ Support for children influencing government decisions } \\
\hline \multicolumn{5}{|c|}{ Likert scale } \\
\hline Children age $3-5$ & 1.89 & 0.95 & 1 & 5 \\
\hline Children age $6-10$ & 2.07 & 1.02 & 1 & 5 \\
\hline Children age $11-14$ & 2.64 & 1.19 & 1 & 5 \\
\hline Children age $15-18$ & 3.56 & 1.13 & 1 & 5 \\
\hline \multicolumn{5}{|l|}{ Explanatory variables } \\
\hline \multicolumn{5}{|l|}{ Gender } \\
\hline Male & $47.79 \%$ & & 0 & 1 \\
\hline Female & $52.21 \%$ & & 0 & 1 \\
\hline \multicolumn{5}{|l|}{ Age group } \\
\hline $18-30$ years & $19.72 \%$ & & 0 & 1 \\
\hline $31-45$ years & $24.98 \%$ & & 0 & 1 \\
\hline $46-60$ years & $28.28 \%$ & & 0 & 1 \\
\hline Over 60 years & $27.01 \%$ & & 0 & 1 \\
\hline \multicolumn{5}{|l|}{ Education } \\
\hline Degree or higher & $31.26 \%$ & & 0 & 1 \\
\hline Trade or diploma certificate & $29.70 \%$ & & 0 & 1 \\
\hline School certificate & $24.31 \%$ & & 0 & 1 \\
\hline No qualifications & $14.73 \%$ & & 0 & 1 \\
\hline \multicolumn{5}{|l|}{ Country of birth } \\
\hline Not New Zealand born & $22.25 \%$ & & 0 & 1 \\
\hline New Zealand born & $77.75 \%$ & & 0 & 1 \\
\hline \multicolumn{5}{|l|}{ Maori status } \\
\hline Not Maori & $85.70 \%$ & & 0 & 1 \\
\hline Maori & $14.30 \%$ & & 0 & 1 \\
\hline \multicolumn{5}{|l|}{ Religious identification } \\
\hline No religion & $44.22 \%$ & & 0 & 1 \\
\hline Has a religion & $54.17 \%$ & & 0 & 1 \\
\hline No religion info & $1.61 \%$ & & 0 & 1 \\
\hline \multicolumn{5}{|l|}{ Children in the household } \\
\hline No & $55.71 \%$ & & 0 & 1 \\
\hline Yes & $44.29 \%$ & & 0 & 1 \\
\hline \multicolumn{5}{|l|}{ Income levels } \\
\hline Bottom quartile & $6.97 \%$ & & 0 & 1 \\
\hline Middle two quartiles & $29.74 \%$ & & 0 & 1 \\
\hline Top quartile & $48.27 \%$ & & 0 & 1 \\
\hline No income information & $15.02 \%$ & & 0 & 1 \\
\hline \multicolumn{5}{|l|}{ Political party preference } \\
\hline Labor Party & $22.69 \%$ & & 0 & 1 \\
\hline National Party & $44.15 \%$ & & 0 & 1 \\
\hline Greens & $9.30 \%$ & & 0 & 1 \\
\hline New Zealand First & $6.27 \%$ & & 0 & 1 \\
\hline Other party & $3.91 \%$ & & 0 & 1 \\
\hline No vote or no information & $13.68 \%$ & & 0 & 1 \\
\hline
\end{tabular}

Notes: NZAVS data, 2016 (weighted for differential non-response). $n=1,264$.

\section{Multivariate ordered logistic regression models}

We model the multivariate associations between socio-demographic factors and the ordered measures of support for children having opportunities to influence government decisions using ordered logistic regression models. Socio-demographic traits are known to affect youth's civic engagement (e.g. Lochocki 2010), so we assessed if they also influenced adult support for children and youth political participation. In Tables 3 and 4, we express the model results as odds ratios (ORs): ORs greater than 1 denote that an independent variable increases the odds of being in a higher category (i.e. stronger support), whereas ORs lower than 1 denote that an independent variable lowers such odds (i.e. weaker support). For the interested reader, Appendix Table A1 and A2 present the conditional probabilities predicted 


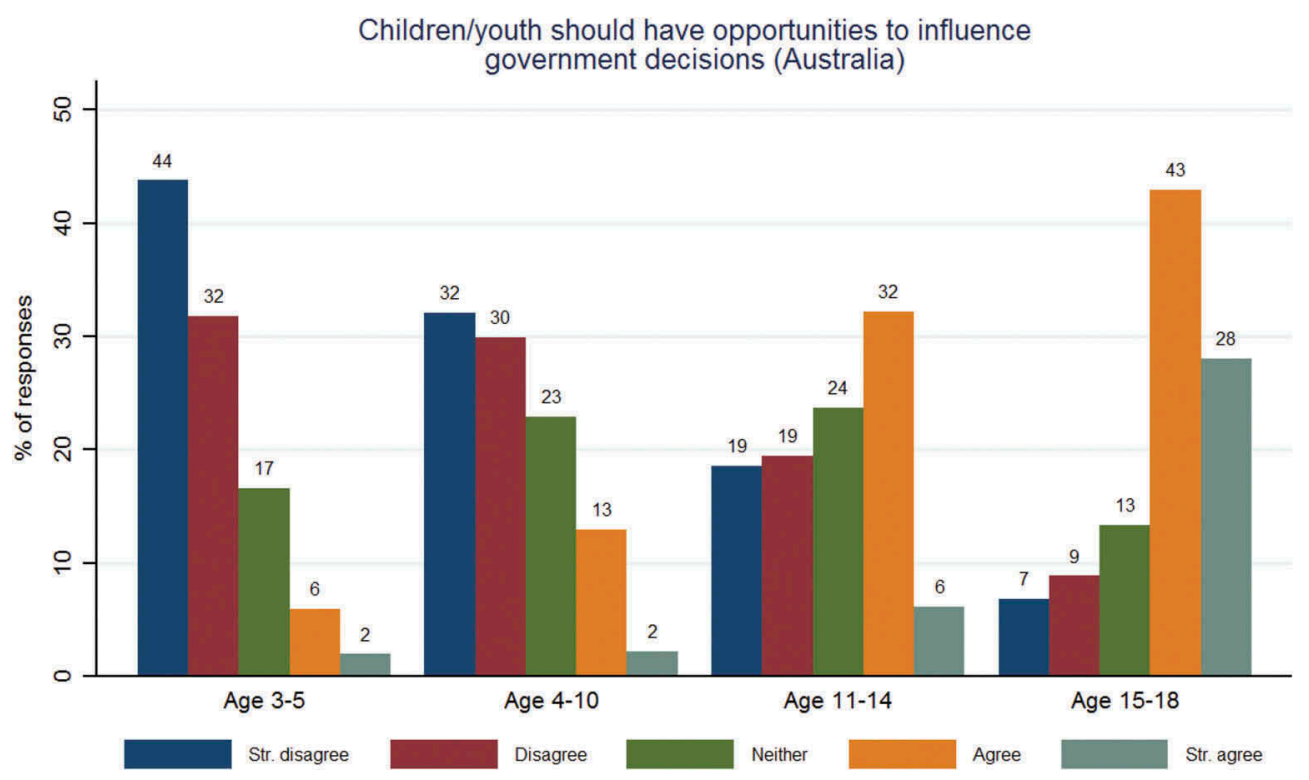

Figure 1. Distribution of support for children influencing government decision variable (Likert scale), Australia.

Notes: AuSSA data, 2016.

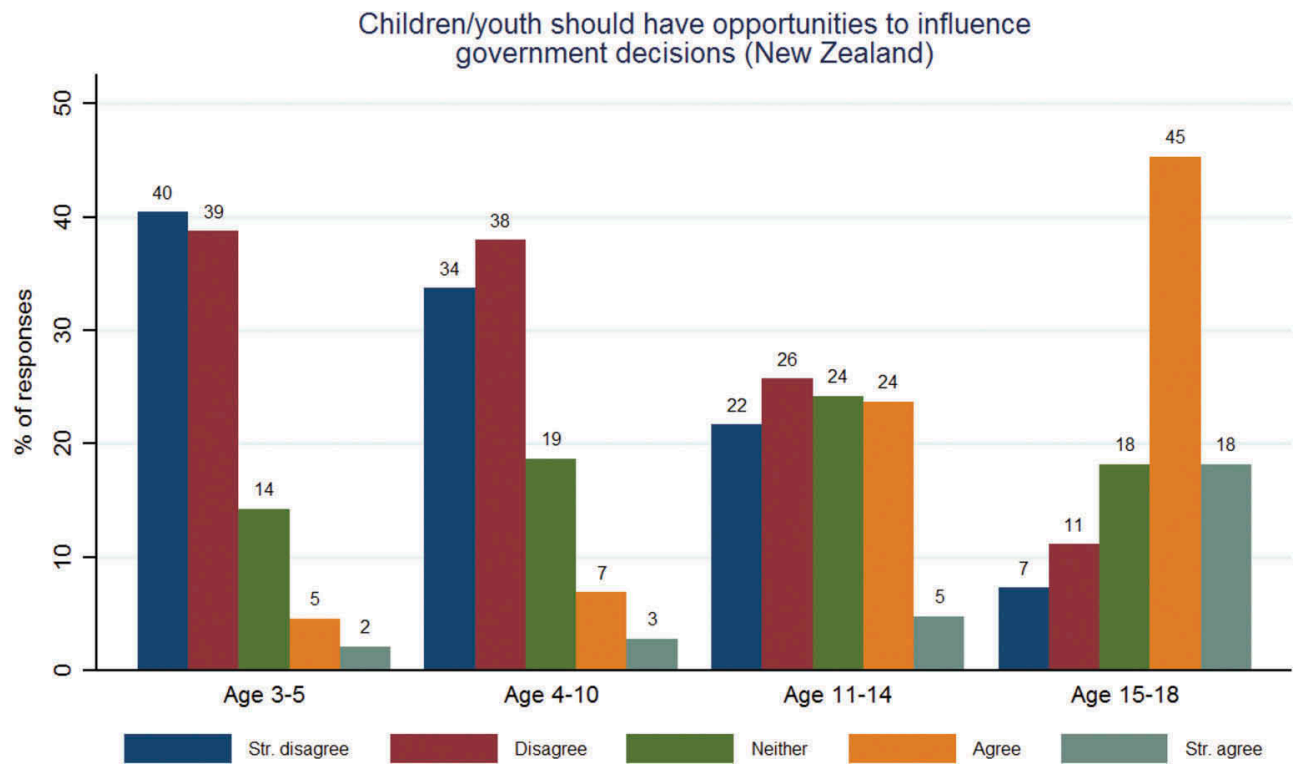

Figure 2. Distribution of support for children influencing government decision variable (Likert scale), New Zealand.

Notes: NZAVS data, 2016. 
from these models while holding the covariates at their means. These predicted probabilities are indicative of effect magnitude.

Estimates from our ordered logistic regression models for Australia are presented in Table 3. All else being equal, women are more supportive of children being able to influence government decisions than men, irrespective of the age of the child asked about. For instance, the adjusted odds of support for the question on children age 15-18 for women were almost twice the odds for men $(\mathrm{OR}=1.99 ; p<0.01)$. There was also a consistent age pattern, whereby individuals in the younger age group (18-30 years) were significantly

Table 3. Odds ratios from ordered logistic regression models of support for children having opportunities to influence government decisions, Australia.

\begin{tabular}{|c|c|c|c|c|}
\hline Child age ... & 3 to 5 & 6 to 10 & 11 to 14 & 15 to 18 \\
\hline $\begin{array}{l}\text { Gender (ref. male) } \\
\text { Female }\end{array}$ & $\begin{array}{l}1.57^{* * *} \\
(0.26)\end{array}$ & $\begin{array}{l}1.58^{* * *} \\
(0.25)\end{array}$ & $\begin{array}{l}2.04^{* * * *} \\
(0.30)\end{array}$ & $\begin{array}{l}1.99^{* * *} \\
(0.31)\end{array}$ \\
\hline \multicolumn{5}{|l|}{ Age group (ref. $18-30$ years) } \\
\hline $31-45$ years & $\begin{array}{c}0.93 \\
(0.29)\end{array}$ & $\begin{array}{c}0.74 \\
(0.22)\end{array}$ & $\begin{array}{c}0.68 \\
(0.17)\end{array}$ & $\begin{array}{l}0.55^{* *} \\
(0.16)\end{array}$ \\
\hline $46-60$ years & $\begin{array}{l}0.52^{* * *} \\
(0.12)\end{array}$ & $\begin{array}{l}0.50^{* * *} \\
(0.11)\end{array}$ & $\begin{array}{c}0.64^{*} \\
(0.16)\end{array}$ & $\begin{array}{l}0.56^{* *} \\
(0.16)\end{array}$ \\
\hline Over 60 years & $\begin{array}{l}0.59^{* *} \\
(0.15)\end{array}$ & $\begin{array}{l}0.50^{* * *} \\
(0.12)\end{array}$ & $\begin{array}{l}0.50^{* *} \\
(0.14)\end{array}$ & $\begin{array}{l}0.54^{* *} \\
(0.16)\end{array}$ \\
\hline \multicolumn{5}{|c|}{ Education (ref. Degree or higher) } \\
\hline Professional qualification & $\begin{array}{l}1.55^{* * *} \\
(0.25)\end{array}$ & $\begin{array}{c}1.26 \\
(0.21)\end{array}$ & $\begin{array}{c}0.90 \\
(0.16)\end{array}$ & $\begin{array}{c}0.77 \\
(0.13)\end{array}$ \\
\hline School year 12 & $\begin{array}{c}1.10 \\
(0.31)\end{array}$ & $\begin{array}{c}1.08 \\
(0.28)\end{array}$ & $\begin{array}{c}0.81 \\
(0.20)\end{array}$ & $\begin{array}{c}0.89 \\
(0.21)\end{array}$ \\
\hline Below school year 12 & $\begin{array}{l}1.94^{* *} \\
(0.53)\end{array}$ & $\begin{array}{c}1.46 \\
(0.36)\end{array}$ & $\begin{array}{c}0.91 \\
(0.21)\end{array}$ & $\begin{array}{l}0.66^{*} \\
(0.16)\end{array}$ \\
\hline \multicolumn{5}{|c|}{ Country of birth (ref. Not Australian born) } \\
\hline Australian born & $\begin{array}{l}0.63^{* *} \\
(0.12)\end{array}$ & $\begin{array}{l}0.61^{* * *} \\
(0.11)\end{array}$ & $\begin{array}{l}0.65^{* *} \\
(0.12)\end{array}$ & $\begin{array}{c}0.91 \\
(0.15)\end{array}$ \\
\hline \multicolumn{5}{|c|}{ Indigenous status (ref. Not Indigenous) } \\
\hline Indigenous & $\begin{array}{c}1.02 \\
(0.42)\end{array}$ & $\begin{array}{c}0.87 \\
(0.30)\end{array}$ & $\begin{array}{c}0.89 \\
(0.31)\end{array}$ & $\begin{array}{c}0.92 \\
(0.50)\end{array}$ \\
\hline \multicolumn{5}{|c|}{ Religious identification (ref. No religion) } \\
\hline Has a religion & $\begin{array}{c}0.85 \\
(0.14)\end{array}$ & $\begin{array}{c}1.00 \\
(0.15)\end{array}$ & $\begin{array}{c}0.85 \\
(0.13)\end{array}$ & $\begin{array}{c}0.94 \\
(0.15)\end{array}$ \\
\hline No religion info & $\begin{array}{c}1.60 \\
(0.91)\end{array}$ & $\begin{array}{c}1.52 \\
(0.86)\end{array}$ & $\begin{array}{c}1.22 \\
(0.47)\end{array}$ & $\begin{array}{c}1.22 \\
(0.49)\end{array}$ \\
\hline \multicolumn{5}{|c|}{ Children in the household (ref. No children) } \\
\hline Children & $\begin{array}{c}0.91 \\
(0.19)\end{array}$ & $\begin{array}{c}1.07 \\
(0.20)\end{array}$ & $\begin{array}{c}0.92 \\
(0.17)\end{array}$ & $\begin{array}{c}0.81 \\
(0.16)\end{array}$ \\
\hline \multicolumn{5}{|c|}{ Income level (ref. Bottom quartile) } \\
\hline Middle 2 quartiles & $\begin{array}{c}1.07 \\
(0.25)\end{array}$ & $\begin{array}{c}0.93 \\
(0.21)\end{array}$ & $\begin{array}{c}1.15 \\
(0.22)\end{array}$ & $\begin{array}{c}1.09 \\
(0.24)\end{array}$ \\
\hline Top quartile & $\begin{array}{c}0.73 \\
(0.20)\end{array}$ & $\begin{array}{c}0.73 \\
(0.20)\end{array}$ & $\begin{array}{c}0.94 \\
(0.24)\end{array}$ & $\begin{array}{c}0.99 \\
(0.30)\end{array}$ \\
\hline No income info & $\begin{array}{c}1.17 \\
(0.28)\end{array}$ & $\begin{array}{c}0.95 \\
(0.20)\end{array}$ & $\begin{array}{c}1.02 \\
(0.21)\end{array}$ & $\begin{array}{c}0.98 \\
(0.22)\end{array}$ \\
\hline$n$ & 1,146 & 1,146 & 1,146 & 1,146 \\
\hline Pseudo $R^{2}$ & 0.03 & 0.02 & 0.02 & 0.02 \\
\hline Likelihood ratio $\mathrm{Chi}^{2}$ test & 38.79 & 48.77 & 53.48 & 45.07 \\
\hline$p$ & $<0.01$ & $<0.01$ & $<0.01$ & $<0.01$ \\
\hline
\end{tabular}

Notes: AuSSA data, 2016 (weighted for differential non-response). Standard errors in parentheses.

Statistical significance: ${ }^{*} p<0.1,{ }^{* *} p<0.05,{ }^{* *} p<0.01$. 
more likely than individuals in all other age groups to express support. Differences between individuals in the other age groups were minor. Individuals with University qualifications were less likely than those with professional qualifications $(\mathrm{OR}=1.55 ; p<0.001)$ and those with below year 12 education $(\mathrm{OR}=1.94 ; p<0.05)$ to support the notion of young children age 3-5 influencing government decisions. However, University-educated individuals were more likely to support influence by children ages 15-18 than individuals with below year 12 education $(\mathrm{OR}=0.66 ; p<0.01)$. Comparing Australian-born and non-Australian-born individuals, the former were significantly less likely to support influence in government

Table 4. Odds ratios from ordered logistic regression models support for children having opportunities to influence government decisions, New Zealand.

\begin{tabular}{|c|c|c|c|c|}
\hline Child age ... & 3 to 5 & 6 to 10 & 11 to 14 & 15 to 18 \\
\hline $\begin{array}{l}\text { Gender (ref. male) } \\
\text { Female }\end{array}$ & $\begin{array}{l}1.50^{* * * *} \\
(0.17)\end{array}$ & $\begin{array}{l}1.60^{* * *} \\
(0.18)\end{array}$ & $\begin{array}{l}1.70^{* * * *} \\
(0.19)\end{array}$ & $\begin{array}{l}1.53^{* * *} \\
(0.18)\end{array}$ \\
\hline \multicolumn{5}{|l|}{ Age group (ref. $18-30$ years) } \\
\hline $31-45$ years & $\begin{array}{c}1.10 \\
(0.19)\end{array}$ & $\begin{array}{c}0.98 \\
(0.17)\end{array}$ & $\begin{array}{c}1.08 \\
(0.18)\end{array}$ & $\begin{array}{c}1.01 \\
(0.18)\end{array}$ \\
\hline $46-60$ years & $\begin{array}{c}0.66^{* *} \\
(0.11)\end{array}$ & $\begin{array}{l}0.66^{* *} \\
(0.11)\end{array}$ & $\begin{array}{c}0.88 \\
(0.15)\end{array}$ & $\begin{array}{c}1.00 \\
(0.17)\end{array}$ \\
\hline Over 60 years & $\begin{array}{l}0.54^{* * *} \\
(0.09)\end{array}$ & $\begin{array}{l}0.59^{* * *} \\
(0.10)\end{array}$ & $\begin{array}{l}0.72^{* *} \\
(0.11)\end{array}$ & $\begin{array}{c}0.74^{*} \\
(0.13)\end{array}$ \\
\hline \multicolumn{5}{|c|}{ Education (ref. Degree or higher) } \\
\hline Trade or diploma certificate & $\begin{array}{l}1.49^{* * *} \\
(0.22)\end{array}$ & $\begin{array}{c}1.11 \\
(0.16)\end{array}$ & $\begin{array}{c}0.97 \\
(0.14)\end{array}$ & $\begin{array}{l}0.63^{* * *} \\
(0.09)\end{array}$ \\
\hline School certificate & $\begin{array}{c}1.14 \\
(0.19)\end{array}$ & $\begin{array}{c}0.93 \\
(0.14)\end{array}$ & $\begin{array}{c}0.99 \\
(0.15)\end{array}$ & $\begin{array}{c}0.89 \\
(0.14)\end{array}$ \\
\hline No qualifications & $\begin{array}{l}1.79^{* * *} \\
(0.37)\end{array}$ & $\begin{array}{c}1.27 \\
(0.25)\end{array}$ & $\begin{array}{c}0.88 \\
(0.17)\end{array}$ & $\begin{array}{l}0.57^{* * *} \\
(0.11)\end{array}$ \\
\hline \multicolumn{5}{|c|}{ Country of birth (ref. Not New Zealand born) } \\
\hline New Zealand born & $\begin{array}{c}0.90 \\
(0.13)\end{array}$ & $\begin{array}{c}0.87 \\
(0.12)\end{array}$ & $\begin{array}{c}0.85 \\
(0.11)\end{array}$ & $\begin{array}{c}0.93 \\
(0.14)\end{array}$ \\
\hline \multicolumn{5}{|l|}{ Maori status (ref. Not Maori) } \\
\hline Maori & $\begin{array}{l}1.75^{* * *} \\
(0.31)\end{array}$ & $\begin{array}{l}1.64^{* * * *} \\
(0.28)\end{array}$ & $\begin{array}{c}1.29 \\
(0.22)\end{array}$ & $\begin{array}{c}1.05 \\
(0.19)\end{array}$ \\
\hline \multicolumn{5}{|c|}{ Religious identification (ref. No religion) } \\
\hline Has a religion & $\begin{array}{c}1.06 \\
(0.13)\end{array}$ & $\begin{array}{c}1.02 \\
(0.12)\end{array}$ & $\begin{array}{c}0.89 \\
(0.10)\end{array}$ & $\begin{array}{c}0.86 \\
(0.10)\end{array}$ \\
\hline No religion info & $\begin{array}{c}1.16 \\
(0.35)\end{array}$ & $\begin{array}{c}0.97 \\
(0.31)\end{array}$ & $\begin{array}{c}1.09 \\
(0.37)\end{array}$ & $\begin{array}{l}0.37^{* * *} \\
(0.13)\end{array}$ \\
\hline \multicolumn{5}{|c|}{ Children in the household (ref. No children) } \\
\hline Children & $\begin{array}{l}1.31^{* *} \\
(0.16)\end{array}$ & $\begin{array}{l}1.31^{* *} \\
(0.16)\end{array}$ & $\begin{array}{l}1.27^{* *} \\
(0.15)\end{array}$ & $\begin{array}{l}1.16 \\
(0.14)\end{array}$ \\
\hline \multicolumn{5}{|c|}{ Income level (ref. Bottom quartile) } \\
\hline Middle 2 quartiles & $\begin{array}{c}0.94 \\
(0.21)\end{array}$ & $\begin{array}{c}0.84 \\
(0.19)\end{array}$ & $\begin{array}{c}1.02 \\
(0.23)\end{array}$ & $\begin{array}{c}0.99 \\
(0.22)\end{array}$ \\
\hline Top quartile & $\begin{array}{c}0.66^{*} \\
(0.15)\end{array}$ & $\begin{array}{l}0.61^{* *} \\
(0.15)\end{array}$ & $\begin{array}{c}0.72 \\
(0.17)\end{array}$ & $\begin{array}{c}0.71 \\
(0.16)\end{array}$ \\
\hline No income info & $\begin{array}{c}1.05 \\
(0.26)\end{array}$ & $\begin{array}{c}0.85 \\
(0.22)\end{array}$ & $\begin{array}{c}0.84 \\
(0.21)\end{array}$ & $\begin{array}{c}0.71 \\
(0.19)\end{array}$ \\
\hline$n$ & 1,264 & 1,264 & 1,264 & 1,264 \\
\hline Pseudo $R^{2}$ & 0.03 & 0.02 & 0.02 & 0.02 \\
\hline Likelihood ratio $\mathrm{Chi}^{2}$ test & 79.27 & 68.14 & 57.68 & 59.43 \\
\hline$p$ & $<0.01$ & $<0.01$ & $<0.01$ & $<0.01$ \\
\hline
\end{tabular}

Notes: NZAVS data, 2016 (weighted for differential non-response). Standard errors in parentheses.

Statistical significance: ${ }^{*} p<0.1,{ }^{* *} p<0.05,{ }^{* *} p<0.01$. 
decisions by children age $3-5(\mathrm{OR}=0.63 ; p<0.05)$, children age $6-10(\mathrm{OR}=0.61 ; p<0.01)$ and children age $11-14(\mathrm{OR}=0.65 ; p<0.05)$. There were however no differences by Indigenous status, religion, presence of children in the household or income.

The analogous results for New Zealand are presented in Table 4. Women were significantly more likely to support children of all ages influencing government decisions, ceteris paribus. For instance, for the question about children in the oldest age group, the odds ratio was $1.53(p<0.01)$. Concerning age, respondents over 60 years were significantly less likely than those in the youngest group to support influence by children ages $3-5(\mathrm{OR}=$ $0.54 ; p<0.01), 6-10(\mathrm{OR}=0.59 ; p<0.01), 11-14(\mathrm{OR}=0.72 ; p<0.05)$, and $15-18(\mathrm{OR}=0.74$, $p<0.1$ ). Respondents aged 46-60 years were also significantly less likely to support influence by children ages 3-5 (OR $=0.66 ; p<0.05)$ and 6-10 (OR $=0.66 ; p<0.05)$. There were a few differences in support by education level in the New Zealand sample. Exceptions included a higher likelihood to support the notion of children age 15-18 influencing government decisions amongst University-educated respondents compared to those with trade/diploma certificates $(\mathrm{OR}=0.63 ; p<0.01)$ and those with no qualifications $(\mathrm{OR}=0.57 ; p<0.01)$. There was also a predisposition for individuals with trade/ diploma certificates $(\mathrm{OR}=1.49 ; p<0.01)$ and no qualifications to express greater support $(\mathrm{OR}=1.79 ; p<0.01)$ for children $3-5$ influencing Government decisions than their degreeeducated peers. Respondents who identified as Māori were significantly more likely to express support for children age $3-5(\mathrm{OR}=1.75 ; p<0.01)$ and age $6-10(\mathrm{OR}=1.64 ; p<0.01)$ influencing government decisions. Respondents who had children in the household were more likely to express support for participation amongst children aged 3-5 years ( $\mathrm{OR}=$ $1.31 ; p<0.05), 6-10$ years $(\mathrm{OR}=1.31 ; p<0.05)$ and $11-14$ years $(\mathrm{OR}=1.27 ; p<0.05)$. Compared to respondents in the bottom income quartile, New Zealand respondents in the top income quartile were significantly less likely to support the influence of children age 3-5 $(\mathrm{OR}=0.66 ; p<0.1)$ and $6-10(\mathrm{OR}=0.61 ; p<0.05)$, but equally likely to support the influence of adolescents aged 11-14 ( $p>0.1)$ and 15-18 ( $p>0.1)$. No statistically significant differences were found by country of birth or religious identification.

Altogether, the models explained between $2 \%$ and $3 \%$ of the variation in the outcome variable in both the Australian and New Zealand weighted data - as denoted by the pseudo$\mathrm{R}^{2}$ statistics. This suggests that attitudes towards children influencing government decisions are difficult to predict statistically: they are either structured by other socio-demographic factors not included in the models, or by individual idiosyncrasies. The models for younger children had slightly higher pseudo- $\mathrm{R}^{2}$ values than the models for older children, which suggests that predicting attitudes towards teenagers influencing government decisions is particularly challenging. Despite the low predictive power of the models, the $p$ values on the likelihood ratio $\mathrm{Chi}^{2}$ tests were always smaller than 0.01 , which constitutes conclusive evidence that multivariate models are preferable to bivariate analyses.

\section{Political party preferences}

In a final set of ordered logistic regression models, we examined the influence of political party preferences (Tables 5 and 6). In these specifications, we only include a set of dummy variables capturing the political party for which the respondent voted in the last general election. ${ }^{3}$

Results for Australia are presented in Table 5. Compared to respondents who voted for the Coalition, those who voted for the Labor Party, the Greens, or other parties were 
Table 5. Odds ratios from ordered logistic regression models of support for children having opportunities to influence government decisions (party identification), Australia.

\begin{tabular}{lllll}
\hline \multicolumn{1}{l}{ Child age ... } & 3 to 5 & 6 to 10 & 11 to 14 & 15 to 18 \\
\hline $\begin{array}{l}\text { Party voted for in last general election (ref. Coalition) } \\
\text { Labor Party }\end{array}$ & $1.66^{* * *}$ & $1.65^{* * *}$ & $1.69^{* * *}$ & $1.92^{* * *}$ \\
& $(0.31)$ & $(0.31)$ & $(0.28)$ & $(0.38)$ \\
Greens & $2.91^{* * *}$ & $3.14^{* * *}$ & $3.77^{* * *}$ & $3.86^{* * *}$ \\
& $(0.81)$ & $(0.87)$ & $(1.02)$ & $(0.93)$ \\
Other party & $1.84^{* *}$ & $2.15^{* * *}$ & $1.82^{* * *}$ & $1.61^{*}$ \\
& $(0.46)$ & $(0.51)$ & $(0.41)$ & $(0.40)$ \\
No vote or no information & 1.23 & 1.43 & $2.50^{* * *}$ & $2.51^{* * *}$ \\
& $(0.40)$ & $(0.37)$ & $(0.82)$ & $(0.86)$ \\
\hline$n$ & 1,146 & 1,146 & 1,146 & 1,146 \\
Pseudo $\mathrm{R}^{2}$ & 0.01 & 0.02 & 0.02 & 0.02 \\
Likelihood ratio Chi ${ }^{2}$ test & 19.56 & 23.86 & 32.66 & 36.13 \\
$p$ & $<0.01$ & $<0.01$ & $<0.01$ & $<0.01$ \\
\hline
\end{tabular}

Notes: AuSSA data, 2016 (weighted for differential non-response). Standard errors in parentheses.

Statistical significance: ${ }^{*} p<0.1,{ }^{* *} p<0.05,{ }^{* *} p<0.01$.

Table 6. Odds ratios from ordered logistic regression models of support for children having opportunities to influence government decisions (party identification), New Zealand.

\begin{tabular}{lcccc}
\hline Child age ... & 3 to 5 & 6 to 10 & 11 to 14 & 15 to 18 \\
\hline $\begin{array}{l}\text { Party voted for in last general election (ref. National Party) } \\
\text { Labor Party }\end{array}$ & $1.69^{* * *}$ & $1.74^{* * *}$ & $1.48^{* * *}$ & $1.45^{* *}$ \\
& $(0.25)$ & $(0.25)$ & $(0.21)$ & $(0.22)$ \\
Greens & 1.37 & $1.83^{* * *}$ & $1.99^{* * *}$ & $2.01^{* * *}$ \\
& $(0.29)$ & $(0.39)$ & $(0.44)$ & $(0.41)$ \\
New Zealand First & 1.29 & 1.35 & 1.11 & 1.13 \\
& $(0.30)$ & $(0.29)$ & $(0.22)$ & $(0.28)$ \\
Other party & $2.14^{* *}$ & $3.09^{* * *}$ & $1.80^{*}$ & $2.15^{* *}$ \\
& $(0.68)$ & $(1.04)$ & $(0.60)$ & $(0.68)$ \\
No vote or no information & $1.65^{* * *}$ & $1.53^{* *}$ & 1.18 & 1.00 \\
& $(0.29)$ & $(0.26)$ & $(0.18)$ & $(0.17)$ \\
\hline$n$ & 1,264 & 1,264 & 1,264 & 1,264 \\
Pseudo R & 0.01 & 0.01 & 0.01 & 0.01 \\
Likelihood ratio Chi ${ }^{2}$ test & 20.78 & 28.01 & 16.63 & 19.81 \\
$p$ & $<0.01$ & $<0.01$ & 0.01 & $<0.01$ \\
\hline
\end{tabular}

Notes: NZAVS data, 2016 (weighted for differential non-response). Standard errors in parentheses.

Statistical significance: ${ }^{*} p<0.1,{ }^{* *} p<0.05,{ }^{* * *} p<0.01$

comparatively more likely to support children of all ages influencing government decisions. Comparisons between respondents who voted for the Labor Party, and respondents who voted for the Green Party (not shown in the tables) revealed that the latter were significantly more likely to support children of all ages influencing government decisions.

Results for New Zealand are presented in Table 6. Compared to respondents who voted for the National Party, those who voted for the Labour Party were significantly more likely to support children of all ages influencing government decisions, and those who voted for the Green Party were more supportive across the 6-18 age range. Respondents who voted for other parties were also more likely than those voting for the National Party to express support of children in all four age ranges influencing 
government decisions. There were no statistically significant differences between National Party and New Zealand First voters. Additional contrasts between respondents voting for Labour and respondents voting for the Green Party (not shown) revealed that there were no statistically significantly differences in any of the outcome variables between these groups.

The magnitude of the odds ratios across these models is generally large (particularly for the Australian sample), suggesting that political views are an important factor structuring attitudes towards children influencing government decisions. Yet, collectively, political party preferences explain only about $1 \%$ to $2 \%$ of the variance in support in Australia, and $1 \%$ in New Zealand. Nevertheless, the $p$ values on the likelihood ratio $\mathrm{Chi}^{2}$ tests confirm that multivariate models are preferable to bivariate analyses.

\section{Discussion}

Analyses of the survey responses provide some indication of a socio-demographic patterning in support for children and youth having influence on governmental decisions, along with indication of political ontologies that are more egalitarian being more supportive. These results offer some specification to identify the discursive conditions for the emergence of collective action that challenges relations of subordination for children and youth, perhaps not dissimilar to the discursive conditions that enabled feminism to rise in modern times and not in previous eras (Laclau and Mouffe 1985). How respondents perceive children and youth, democracy, and political participation would have informed their responses. We thus examined the most significant indicators of support (preference for 15-18 year olds, and respondents who identified as 18-30 years of age, women, Māori and Labor/Labour, Green party voters) to identify influencing discourses/narratives that shape respondent perceptions of children and youth, and democracy, political participation.

Being closest in age to those for whom political participation is being surveyed increased the likelihood of support. This can be appreciated in the predicted probabilities for the youngest group of respondents aged 18-30 years in Appendix Tables A1 and A2; compared to respondents aged 60+ years, the youngest respondents were 3 to 14 percentage points less likely to fall into the 'strongly disagree' category in the Australian data, and 2 to 15 percentage points in the New Zealand data - depending on the age range of the children asked about. Young respondents may empathise with children and youth because they recognise a desire for political participation that they may have held in the not so distant past, or because they too are still framed by societal tropes and discourses that position them as apathetic, disengaged and unreliable. Widespread perception of children as developing influenced by the maturational theory of child development (e.g. Gesell 1928; Piaget 1952) embedded in social policy (e.g. agebased schooling), would have played into respondents increased support for youth aged 15-18 to have the means to influence government decisions over younger age groups. The limited support by respondents in both Australia and New Zealand, for younger children to influence government could be influenced by a narrow view of the opportunities that exist for younger age-groups, and/or a view of younger children as less competent and capable than older children. Developmental psychologists perpetuate this perception with claims of universalistic civic development, such as the proposition 
that 'the capacity to assess whether and how to be involved along with the motivation to fulfil roles as responsible and active citizens are usually acquired by the end of adolescence' (Torney-Purta and Amadeo 2013, 90). Some respondents may also perceive children and youth as impulsive and therefore irrational, as some commentators expressed in response to our Conversation article (Phillips, Ritchie \& Perales 2017) on these survey results. Further, some may perceive childhood to be a time of innocence, and for children not to be troubled with societal issues. Others may suspect that younger children would be under the influence of parental ideologies, and incapable of independent thought: child as immanent.

Australian and New Zealand women were statistically significantly more supportive of children and youth political participation across all age groups being able to influence government decisions than men. The magnitude of the effects was often large, as reflected in Appendix Tables A1 and A2. For example, when asked about children ages 3-5, women in the Australian and New Zealand samples were 11 and 10 percentage points less likely than men to fall into the 'strongly disagree' category, respectively. Women have been associated with children across history and social policy, as their main caregivers and well-being advocates. Both groups were excluded from the polis in ancient Greece. It is only comparatively recently in human history that women have gained the right to influence governmental decisions. This legacy and recognition of minoritisation perhaps nudges women to more likely consider a child's position and advocate for their inclusion. Further studies have demonstrated that women are more likely to be civically engaged than men (Wilson 2000) and express higher-levels of pro-social behaviour (Lochocki 2010), also indicating higher support for political participation for all. Women are more likely to have more progressive and inclusive views on other social issues, such as LGBT issues (e.g. see Perales and Campbell 2018).

In the New Zealand data, Māori respondents were significantly and substantially more likely to express support for all ages, especially for children ages 3-10. As a marker of effect magnitude, Māori respondents were 13 percentage points less likely than other respondents to select the 'strongly disagree' category when asked about children ages $3-5$, and 10 percentage points less likely when asked about children ages 6-10 (Appendix Table A2). This finding could be explained by the collective nature of Māori society. From a social constructionist perspective, it could be seen that that Māori values and world view have traditionally been more intergenerationally inclusive and egalitarian than those of western societies in relation to both women and children (Pere 1982; Jenkins and Harte 2011). Māori children are regarded as both rights and knowledge holders (Pere 1982). They participate in the everyday and significant events of their whānau (extended families), accompanying grandparents to political meetings, learning the histories of dispossession of their lands, mountains, lakes and rivers, and growing up to continue these traditions and activities, including the pursuit of redress for historical grievances. Indigenous relationalities differ from the western constructions that are 'universalised' in developmental psychology and other academic disciplines (Mignolo 2012).

In both countries, respondents who vote for political parties to the left of the political spectrum were more likely to support children's participation in influencing government decision-making. In Australia those who vote Labor and the Greens are more 
likely to be egalitarians (Ting 2017), so support participation for all, recognising children's minoritisation or political capacity. The first of the Australian Labor Party's objectives infers inclusion of children ${ }^{4}$ though is not as explicit in its support for children's political rights as The Greens (as noted below). Those who voted for the Greens in Australia were the most likely to support children's governmental influence across all age groups (generally followed by those voting Labor), with those voting the Coalition in Australia and New Zealand First being consistently the least likely to do so. As seen in Appendix Table A2, the magnitude of association for the political party differences was comparatively large. ${ }^{5}$ For example, across the models, Australian respondents voting for the Greens were 7 to 25 percentage points less likely to fall into the 'strongly disagree' category than those voting for the Coalition. Social justice and grass roots democracy are two of the four pillars of The Australian Greens, so that the inclusion of all in decision-making is central to Greens thinking. Key aims of The Greens' Child and Young People's policy include ensuring

that children and young people have the means to express themselves to their community and at all levels of government, through the National Children's Commissioner and other federal or state/territory youth advisory bodies ... Electoral law reform to allow young people aged 16 and 17 to vote ... A national youth affairs peak body with elected and representative members. (The Greens 2017)

With political ontology that foregrounds social justice and grass roots democracy, it makes sense that those who vote for The Greens are more likely to support the inclusion of children and youth's voice in governmental decisions. Australian Green party 'sympathisers are most likely to be young (especially under 25), female, university-educated' (Bennett 2008). And a similar demographic pattern plays out in New Zealand with $67.8 \%$ of greens voters identifying as female and $67.1 \%$ reporting undergraduate or above university education (Cowie, Greaves, Sibley 2015). Youthfulness, gender and university education all consistently presenting as demographic indicators of increased support for children and youth political participation. We also wonder if university education feeds critical thinking so that universalistic constructions of children are questioned and challenged. University educated respondents in our data were more likely to support youth participation (15-18 year olds), though less likely to support young children age 3-5 influencing government decisions, suggesting they may be more discerning of age group capacity.

The New Zealand Labour party has had a long-standing commitment to egalitarian principles, social justice and social welfare, and has thus traditionally garnered greater support from women, trade unions, working people, and Māori (Franks and McAloon 2016). Similarly, the more recently established New Zealand Green Party has articulated strong policies underpinned by a commitment to not only the environment but with a strong social justice focus on the rights of Māori, women and children (Carroll et al. 2009). The New Zealand Green Party's (2013) Children's Policy vision states that 'Each child and young person is an integral part of our society, has access to a quality education and participates in decisions that affect their life, community and the environment' (p. 1) and a key principle is that 'Children have valuable perspectives, so they should be supported in their own initiatives and encouraged to participate in decisions affecting them to the extent that they are able' (p. 1). Despite discussion of this issue (e.g. Howell 2017), neither 
the New Zealand Labour or Green parties have a policy regarding lowering the voting age below the current age of 18 .

Despite the importance and innovative features of this study, a limitation that should be borne in mind in interpreting our results is the relatively low response rate for both the Australian (28.7\%) and New Zealand (33.1\%) surveys. While use of sample weights to correct for non-response should ameliorate any bias to the estimates due to nonresponse, future studies based on larger samples from studies with higher participation rates could be undertaken to add further confidence to our conclusions. Cross-national research investigating the degree of support for children's involvement in Government decision-making in other countries with different institutional environments, historical legacies and socio-demographic makeup should also be undertaken to test the universality of the findings for Australia and New Zealand reported here.

In sum, analysis of 2,410 Australian and New Zealand enrolled voters' indication of their degree of support for children and youth having opportunity to influence governmental decisions points to strong support from respondents who are more likely to care and advocate for children and youth, and to be committed to social justice and grass roots democracy. The swell of support for 15-18 year olds' political voices to be heard across both nations $(71 \%$ in Australia and 63.5\% in New Zealand) offers a strong counter-narrative to the myth that youth are perceived as being politically disengaged. These indicators of support for the political participation of children and youth provide empirical groundings to influence policymakers to follow citizenry preference, as well as identifying socio-demographic groups to which public education programs on children's political rights and capabilities may be focused. The ISSP with 45 member countries, offers a potential means for further national surveying to influence societies towards the cultivation of intergenerational political participation.

As Thomas (2011) argues:

once we say that children have a right to an identity, to a home, to an education or to protection from abuse, we are committing ourselves to a rights-based approach, and so to a view of children as rights-bearing individuals. Once we do that, we have to reckon with their rights to participation and self-determination. (p. 11)

\section{Notes}

1. In both Australia (https://www.aec.gov.au/Elections/referendums/1999_Referendum_ Reports_Statistics/Enrolments.htm) and New Zealand (https://www.govt.nz/browse/ engaging-with-government/enrol-and-vote-in-an-election/enrol-to-vote/) it is compulsory, by law, to be registered in the electoral roll if you are over 18 years of age and a permanent resident of the country. Voting is compulsory in Australia, but not in New Zealand.

2. Assessed through scanning previous ISSP international base survey, AUSSA and ISSPNZ questionnaires for search terms 'child' and 'youth'.

3. We refrain from including the socio-demographic variables in the previous models because these are sometimes highly correlated with political party preferences, and their inclusion may result in issues of multicollinearity. Results adjusting for the control variables are nevertheless available from the authors upon request.

4. 'Redistribution of political and economic power so that all members of society have the opportunity to participate in the shaping and control of the institutions and relationships which determine their lives;' (Australian Labor Party 2015, 4). 
5. However, it must be borne in mind the models for political party differences were intently unadjusted.

\section{Disclosure statement}

No potential conflict of interest was reported by the authors.

\section{Funding}

This work was supported by the Spencer Foundation [201400172] and the ARC Centre of Excellence for Children and Families over the Life Course [CE140100027].

\section{Notes on contributors}

Dr Louise Gwenneth Phillips is an academic in arts and early years education in The School of Education at The University of Queensland, Australia. Her sociological and arts-based research focuses on education's responsibilities to children's rights and citizenship, with key recent coauthored work in this area being the Routledge book Young Children's Community Building in Action: Embodied, Emplaced and Relational Citizenship.

Dr Jenny Ritchie is an Associate Professor in Te Whānau o Ako Pai, the School of Education, at Te Herenga Waka, Victoria University of Wellington, Aotearoa New Zealand. Her research and teaching focuses on social, cultural and ecological justice in education.

Dr. Francisco Perales is Senior Research Fellow \& ARC DECRA Fellow at the Institute for Social Science Research (The University of Queensland). His recent research focuses on understanding socio-economic inequalities by gender and sexual orientation using longitudinal and life-course approaches. His work has been published in outlets such asChild Development, Social Forces, Journal of Marriage \& Family and Social Science \& Medicine.

\section{ORCID}

Louise Gwenneth Phillips (D) http://orcid.org/0000-0002-2937-145X

Jenny Ritchie (D) http://orcid.org/0000-0003-2934-6358

Francisco Perales (D) http://orcid.org/0000-0001-7508-9431

\section{References}

Archard, D. 2015. Children Rights and Childhood. 3rd ed. Abingdon, OX: Routledge.

Arneil, B. 2002. "Becoming versus Being: A Critical Analysis of the Child in Liberal Theory." In The Moral and Political Status of Children, edited by D. Archard and C. M. McLeod, 70-96. Oxford: Oxford University Press.

Australian Labor Party. 2015. "ALP National Constitution.” https://cdn.australianlabor.com.au/ documents/ALP_National_Constitution.pdf

Australian Research Alliance. 2013. "Report Card: The Wellbeing of Young Australians." https:// www.aracy.org.au/publications-resources/command/download_file/id/310/filename/2013Report-Card-The-wellbeing-of-young-Australians.pdf

Bennett, S. 2008. “The Rise of the Australian Greens.” Research Paper No. 8 2008-09, Parliament of Australia. https://www.aph.gov.au/About_Parliament/Parliamentary_Departments/ Parliamentary_Library/pubs/rp/rp0809/09rp08 
Briggs, J. 2017. Young People and Political Participation. Teen Players. London: Palgrave Macmillan.

Bühler-Niederberger, D. 2010. "Introduction: Childhood Sociology - Defining the State of the Art and Ensuring Reflection.” Current Sociology 58 (2): 155-164. doi:10.1177/0011392109354239.

Burstein, P. 1998. "Bringing the Public Back In: Should Sociologists Consider the Impact of Public Opinion on Public Policy?” Social Forces 77: 27-62. doi:10.1093/sf/77.1.27.

Cammaerts, B., M. Bruter, S. Banaji, S. Harrison, and N. Anstead. 2016. Youth Participation in Democratic Life. Stories of Hope and Disillusion. London: Palgrave Macmillan.

Cannella, G. S., and R. Viruru. 2004. Childhood and Postcolonization: Power, Education and Contemporary Practice. New York: RoutledgeFalmer.

Carroll, P., S. Casswell, J. Huakau, P. Perry, and P. H. Chapman. 2009. “Environmental Attitudes, Beliefs about Social Justice and Intention to Vote Green: Lessons for the New Zealand Green Party?” Environmental Politics 18 (2): 257-278. doi:10.1080/09644010802682635.

Coady, M. 1996. "Reflections on Children's Rights." In Citizen Child: Australian Law and Children's Rights, edited by K. Funder, 11-32. Melbourne: Australian Institute of Family Studies.

Cohen, E. F. 2005. "Neither Seen nor Heard: Children's Citizenship in Contemporary Democracies." Citizenship Studies 9 (2): 221-240. doi:10.1080/13621020500069687.

Collin, P. 2015. Young Citizens and Political Participation in a Digital Society Addressing the Democratic Disconnect. London: Palgrave MacMillan.

Connell, R. W. 1971. The Child's Construction of Politics. Melbourne: Melbourne University Press.

Corsaro, W. 1997. The Sociology of Childhood. 2nd ed. Thousand Oaks, CA: Pine Forge Press.

Cowie, L. J., L. M. Greaves, and C. G. Sibley. 2015. "Identifying Distinct Subgroups of Green Voters: A Latent Profile Analysis of Crux Values Relating to Green Party Support." New Zealand Journal of Psychology 1 (4): 45-60.

Dahlberg, G., P. Moss, and A. Pence. 1999. Beyond Quality in Early Childhood Education and Care: Post-modern Perspectives. London: Falmer Press.

de Winter, M. 1997. Children as Fellow Citizens: Participation and Commitment. Abingdon: Radcliffe Medical Press.

Flanagan, C. 2012. Civic Learning/Civic Action: The State of the Field. Commissioned Report for the Spencer Foundation's Strategic Initiative on Civic Learning and Civic Action. Chicago, IL: Spencer Foundation.

Flanagan, C., and P. Levine. 2010. "Civic Engagement and Transition to Adulthood." The Future of Children 20 (1): 159-179.

Franks, P., and J. McAloon. 2016. Labour: The New Zealand Labour Party 1916-2016. Wellington: Victoria University Press.

Freud, S. 1923. The Ego and the Id. New York: W.W. Norton \& Company.

Gesell, A. 1928. Infancy and Human Growth. New York: Macmillan.

Giroux, H. 1983. Theory and Resistance in Education: A Pedagogy for the Opposition. Massachusetts: Bergin \& Garvey.

Green Party of Aotearoa New Zealand. 2013. "Children's Policy.” https://www.greens.org.nz/ sites/default/files/children_20130816.pdf

Harris, R., J. Post, J. Arrieta, and G. Hamelitz-Lopez. 2016. “Adult Perspectives on Nurturing Youth Leadership and Coalition Participation.” In Youth-Community Partnerships for Adolescent Alcohol Prevention, edited by A. J. Romero, 107-123. Cham, Switzerland: Springer International.

Hess, R. D., and J. V. Torney. 1967/2006. The Development of Political Attitudes in Children. Edison, NJ.: Transaction publishers.

Howell, A. 2017. “Time to Lower the Voting Age in New Zealand?” https://www.stuff.co.nz/ national/politics/opinion/96774449/time-to-lower-the-voting-age-in-new-zealand

James, A., C. Jencks, and A. Prout. 1998. Theorizing Childhood. Oxford: Polity Press.

Jenkins, K., and H. M. Harte 2011. Traditional Maori Parenting. An Historical Review of Literature of Traditional Maori Child Rearing Practices in pre-European Times. Auckland. www.ririki.org.nz/wp-content/uploads/2015/04/TradMaoriParenting.pdf 
Kulynych, J. 2001. "No Playing the Public Sphere: Democratic Theory and the Exclusion of Children." Social Theory and Practice 27 (2): 231-265. doi:10.5840/soctheorpract200127211.

Laclau, E., and C. Mouffe. 1985. Hegemony and Socialist Strategy: Towards a Radical Democratic Politics. London: Verso.

Lansdown, G. 2005. Innocenti Insight: The Evolving Capacities of the Child. Florence: UNICEF Innocenti Research Centre.

Lister, R. 2007. "Why Citizenship: Where, When and How Children?" Theoretical Inquiries in Law 8 (2): 693-718. doi:10.2202/1565-3404.1165.

Lister, R. 2008. "Unpacking Children's Citizenship." In Children and Citizenship, edited by A. Invernizzi and J. Williams, 9-19. London: Sage Publications .

Lochocki, T. 2010. Trends, Causes and Patterns of Young People's Civic Engagement in Western Democracies: A Review of Literature. Oslo/Bergen: Centre for Research on Civil Society and Voluntary Sector.

Locke, J. 1690/1959. An Essay Concerning Human Understanding. New York: Dover Publications.

Lundy, L., U. Kilkelly, B. Byrne, and J. Kang 2012. "The UN Convention on the Rights of the Child: A Study of Legal Implementation in 12 Countries.” http://www.unicef.org.uk/ Documents/Publications/UNICEFUK_2012CRCimplementationreport\%20FINAL\%20PDF\% 20version.pdf

Mignolo, W. 2012. Local Histories/global Designs: Coloniality, Subaltern Knowledges, and Border Thinking. Princeton, NJ: Princeton University Press. doi:10.1515/9781400845064.

Milne, B. 2013. The History and Theory of Children's Citizenship in Contemporary Societies. Dordrecht: Springer.

Morrow, V. 1994. "Responsible Children? Aspects of Children's Work and Employment outside School in Contemporary UK." In Children's Childhoods Observed and Experienced, edited by B. Myall, 128-143. London: Falmer Press.

O’Connor, S. 2011. "Community Activities and Youth Wellbeing. Getting Involved, Doing Well, Feeling Connected: How Participation in Community Activities Relates to Positive Developmental Outcomes in a Culturally Diverse Sample of Young New Zealanders." Master of Science in Cross-Cultural Psychology, Victoria University of Wellington. Te Whare Wānanga o te Ūpoko o te Ika a Māui, Wellington.

Oakley, A. 1994. "Women and Children First and Last: Parallels and Differences between Children's and Women's Studies.” In Children's Childhood Observed and Experienced, edited by B. Myall, 13-32. London: Falmer Press.

Perales, F., and A. Campbell. 2018. "Who Supports Equal Rights for Same-Sex Couples? Evidence from Australia." Family Matters 100: 28-41.

Pere, R. R. 1982. Ako. Concepts and Learning in the Maori Tradition. Hamilton: Department of Sociology, University of Waikato. Reprinted in 1994 by Te Kōhanga Reo National Trust Board.

Phillips, L., F. Perales, and J. Ritchie. (2017). Giving voice to the young: Survey shows people wantunder-18sinvolved in politics. The Conversation. Retrieved from https://theconversation. com/giving-voice-to-the-young-survey-shows-people-want-under-18s-involved-in-politics83101

Phillips, L. G. 2010. "Social Justice Storytelling and Young Children's Active Citizenship." Discourse: Studies in the Cultural Politics of Education 31 (4): 363-376.

Piaget, J. 1952. The Origins of Intelligence in Children. New York: International University Press. Prout, A. 2002. "Researching Children as Social Actors: An Introduction to The Children 5-16 Programme.” Children \& Society 16: 67-76. doi:10.1002/(ISSN)1099-0860.

Qvortrup, J. 2003. "Editorial: An Established Field, or a Breakthrough Still Pending?" Childhood 10 (4): 395-400. doi:10.1177/0907568203104001.

Rousseau, J. 1762/2007. Emile: Or, on Education. Sioux Falls, SD: Nu Vision Publications.

Saha, L., M. Print, and K. Edwards. 2005. Youth Electoral Study, Report 2: Youth, Political Engagement and Voting. Canberra: Australian Electoral Commission.

Smith, T. W. "The Globalization of Survey Research." In Survey Methods in Multinational, Multiregional and Multicultural Contexts, edited by J. Harkness, M. Braun, B. Edwards, 
T. Johnson, L. E. Lyberg, P. P. Mohler, B.-E. Pennell, and T. W. Smith, (Ch.25, pp. 475-484). New York: John Wiley, 2010.

Smith, T. W. 2015. "International Social Survey Programme." In International Encyclopedia of the Social and Behavioral Sciences, edited by J. D. Wright, 550-556. 2nd ed. Amsterdam: Elsevier.

Stasiulis, D. 2002. “The Active Child Citizen: Lessons from Canadian Policy and the Children's Movement.” Citizenship Studies 6(4): 507-538. doi:10.1080/1362102022000041286.

The Greens. 2017. "Children and Young People Policy." https://greens.org.au/policies/childrenand-young-people

Thomas, N. 2011. "Children's Rights" Policy into Practice." Centre for Children and Young People: Background Briefing Series, no. 4. Centre for Children and Young People. Lismore, NSW, Australia: Southern Cross University.

Ting, I. 2017. "Comparing the Seven Aussie Personas on Education, Age, Income and Voting Habits." Sydney Morning Herald, February 9. https://www.smh.com.au/national/comparing-theseven-aussie-personas-on-education-age-income-and-voting-habits-20170208-gu8dht.html

Torney-Purta, J., and J. Amadeo. 2013. "The Contributions of International Large-Scale Studies in Civic Education and Engagement." In The Role of International Large-Scale Assessments: Perspectives Form Technology, Economy and Educational Research, edited by M. Von Davier, E. Gonzalez, I. Kirsch, and K. Yamamoto, 87-114. Dordrecht: Springer.

Turner, B. 1993. Citizenship and Social Theory. London: Sage.

UN Committee on the Rights of The Child. 2012. "Convention of the Rights of the Child: Concluding Observations: Australia.” http://www2.ohchr.org/english/bodies/crc/docs/co/ CRC_C_AUS_CO_4.pdf

United Nations. n.d.. “About the Sustainable Development Goals.”https://www.un.org/sustaina bledevelopment/sustainable-development-goals/

United Nations Development Programme. n.d.. "Youth Political Participation and Decision-Making." http://www.un.org/esa/socdev/documents/youth/fact-sheets/youth-

political-participation.pdf

United Nations General Assembly. Convention on the Rights of the Child. New York: United Nations, 1989. http://www.ohchr.org/en/professionalinterest/pages/crc.aspx

Waksler, F. C. 1991. "Studying Children: Phenomenological Insights." In Studying the Social Worlds of Children: Sociological Readings, edited by F. C. Waksler, 60-70. London: Falmer Press.

Wilson, J. 2000. "Volunteering." Annual Review of Sociology 26 (1): 215-240. doi:10.1146/ annurev.soc.26.1.215.

Wood, B. 2011. "Citizenship in our place: Exploring New Zealand young people's everyday, place-based perspectives on participation in society." $\mathrm{PhD}$ thesis, Victoria University of Wellington, Wellington.

$\mathrm{Wu}, \mathrm{I}$., and B. Milne 2017. "Methods and Procedures for the 2016 International Social Survey Programme (ISSP) for New Zealand." Centre of Methods and Policy Application in the Social Sciences (COM PASS). NZ: University of Auckland. http://www.arts.auckland.ac.nz/en/about/ our-research/research-centres-and-archives/compass/compass-projects/international-socialsurvey-programme-issp-.html 
Table A1. Average marginal effects for coefficients in models presented in Tables 3 \& 5 (Australia)

\begin{tabular}{|c|c|c|c|c|}
\hline & \multicolumn{4}{|c|}{ Model for children aged ... } \\
\hline & $\begin{array}{c}3-5 \\
\text { years }\end{array}$ & $\begin{array}{l}6-10 \\
\text { years }\end{array}$ & $\begin{array}{l}11-14 \\
\text { years }\end{array}$ & $\begin{array}{l}15-18 \\
\text { years }\end{array}$ \\
\hline \multicolumn{5}{|l|}{ Female (vs. Male) } \\
\hline Strongly disagree & $-11 \%$ & $-10 \%$ & $-10 \%$ & $-4 \%$ \\
\hline Disagree & $+3 \%$ & $-1 \%$ & $-6 \%$ & $-5 \%$ \\
\hline Neither & $+5 \%$ & $+5 \%$ & n.s. & $-5 \%$ \\
\hline Agree & $+2 \%$ & $+5 \%$ & $+13 \%$ & n.s. \\
\hline Strongly agree & $+1 \%$ & $+1 \%$ & $+4 \%$ & $+14 \%$ \\
\hline \multicolumn{5}{|c|}{ Age: $31-45$ (vs. Age: 18-30) } \\
\hline Strongly disagree & n.s. & n.s. & n.s. & $+3 \%$ \\
\hline Disagree & n.s. & n.s. & n.s. & $+4 \%$ \\
\hline Neither & n.s. & n.s. & n.s. & $+5 \%$ \\
\hline Agree & n.s. & n.s. & n.s. & n.s. \\
\hline Strongly agree & n.s. & n.s. & n.s. & $-13 \%$ \\
\hline \multicolumn{5}{|c|}{ Age: 46-60 (vs. Age: 18-30) } \\
\hline Strongly disagree & $+16 \%$ & $+14 \%$ & $+6 \%$ & $+3 \%$ \\
\hline Disagree & $-4 \%$ & n.s. & $+4 \%$ & $+4 \%$ \\
\hline Neither & $-7 \%$ & $-7 \%$ & n.s. & $+4 \%$ \\
\hline Agree & $-3 \%$ & $-7 \%$ & $-8 \%$ & n.s. \\
\hline Strongly agree & $-1 \%$ & $-1 \%$ & $-3 \%$ & $-12 \%$ \\
\hline \multicolumn{5}{|c|}{ Age: $>60$ (vs. Age: 18-30) } \\
\hline Strongly disagree & $+13 \%$ & $+14 \%$ & $+10 \%$ & $+3 \%$ \\
\hline Disagree & $-3 \%$ & n.s. & $+6 \%$ & $+4 \%$ \\
\hline Neither & $-6 \%$ & $-7 \%$ & n.s. & $+5 \%$ \\
\hline Agree & $-3 \%$ & $-8 \%$ & $-13 \%$ & n.s. \\
\hline Strongly agree & $-1 \%$ & $-1 \%$ & $-4 \%$ & $-13 \%$ \\
\hline \multicolumn{5}{|c|}{ Professional qualification (vs. Higher education) } \\
\hline Strongly disagree & $-11 \%$ & n.s. & n.s. & n.s. \\
\hline Disagree & $+3 \%$ & n.s. & n.s. & n.s. \\
\hline Neither & $+5 \%$ & n.s. & n.s. & n.s. \\
\hline Agree & $+2 \%$ & n.s. & n.s. & n.s. \\
\hline Strongly agree & $+1 \%$ & n.s. & n.s. & n.s. \\
\hline \multicolumn{5}{|c|}{ Below school Year 12 (vs. Higher education) } \\
\hline Strongly disagree & $-16 \%$ & n.s. & n.s. & n.s. \\
\hline Disagree & $+4 \%$ & n.s. & n.s. & n.s. \\
\hline Neither & $+8 \%$ & n.s. & n.s. & $+3 \%$ \\
\hline Agree & $+3 \%$ & n.s. & n.s. & n.s. \\
\hline Strongly agree & $+1 \%$ & n.s. & n.s. & $-8 \%$ \\
\hline \multicolumn{5}{|c|}{ Australian born (vs. Not Australian born) } \\
\hline Strongly disagree & $+11 \%$ & $+10 \%$ & $+6 \%$ & n.s. \\
\hline Disagree & $-2 \%$ & $+2 \%$ & $+4 \%$ & n.s. \\
\hline Neither & $-5 \%$ & $-5 \%$ & n.s. & n.s. \\
\hline Agree & $-3 \%$ & $-5 \%$ & $-8 \%$ & n.s. \\
\hline Strongly agree & n.s. & $-1 \%$ & $-2 \%$ & n.s. \\
\hline \multicolumn{5}{|c|}{ No vote or no information (vs. Coalition) } \\
\hline Strongly disagree & n.s. & n.s. & $-13 \%$ & $-6 \%$ \\
\hline Disagree & n.s. & n.s. & $-8 \%$ & $-6 \%$ \\
\hline Neither & n.s. & n.s. & n.s. & $-7 \%$ \\
\hline Agree & n.s. & n.s. & $+16 \%$ & n.s. \\
\hline Strongly agree & n.s. & n.s. & $+5 \%$ & $+18 \%$ \\
\hline \multicolumn{5}{|c|}{ Labour Party (vs. Coalition) } \\
\hline Strongly disagree & $-13 \%$ & $-11 \%$ & $-9 \%$ & $-4 \%$ \\
\hline Disagree & $+4 \%$ & n.s. & $-4 \%$ & $-5 \%$ \\
\hline Neither & $+5 \%$ & $+6 \%$ & $+1 \%$ & $-5 \%$ \\
\hline Agree & $+2 \%$ & $+5 \%$ & $+9 \%$ & $+2 \%$ \\
\hline Strongly agree & $+1 \%$ & $+1 \%$ & $+2 \%$ & $+12 \%$ \\
\hline \multicolumn{5}{|c|}{ Greens (vs. Coalition) } \\
\hline Strongly disagree & $-25 \%$ & $-23 \%$ & $-17 \%$ & $-7 \%$ \\
\hline
\end{tabular}


(Continued).

\begin{tabular}{lcccc}
\hline & \multicolumn{3}{c}{ Model for children aged ... } \\
\cline { 2 - 4 } & $3-5$ & $6-10$ & $11-14$ & $15-18$ \\
& years & years & years & years \\
\hline Disagree & $+4 \%$ & $-4 \%$ & $-11 \%$ & $-8 \%$ \\
Neither & $+12 \%$ & $+11 \%$ & n.s. & $-10 \%$ \\
Agree & $+6 \%$ & $+13 \%$ & $+23 \%$ & n.s. \\
Strongly agree & $+2 \%$ & $+3 \%$ & $+9 \%$ & $+28 \%$ \\
Other party (vs. Coalition) & & & $-10 \%$ & $-4 \%$ \\
Strongly disagree & $-15 \%$ & $-16 \%$ & $-5 \%$ & $-4 \%$ \\
Disagree & $+4 \%$ & $n . s$. & $n .5$ & $-3 \%$ \\
Neither & $+7 \%$ & $+8 \%$ & $+11 \%$ & $+2 \%$ \\
Agree & $+3 \%$ & $+8 \%$ & $+3 \%$ & $+8 \%$ \\
Strongly agree & n.s. & $+2 \%$ & & $+3 \%$ \\
\hline
\end{tabular}

Notes: Cells give the difference (in percentage points) in the proportion of cases in a variable category predicted to fall into each of the five response options relative to the reference category, adjusting for any covariates. n.s.: nonsignificant.

Table A2. Average marginal effects for coefficients in models presented in Tables 4 \& Tables 6 (New Zealand)

\begin{tabular}{|c|c|c|c|c|}
\hline & \multicolumn{4}{|c|}{ Model for children aged ... } \\
\hline & $\begin{array}{c}3-5 \\
\text { years }\end{array}$ & $\begin{array}{l}6-10 \\
\text { years }\end{array}$ & $\begin{array}{l}11-14 \\
\text { years }\end{array}$ & $\begin{array}{l}15-18 \\
\text { years }\end{array}$ \\
\hline \multicolumn{5}{|l|}{ Female (vs. Male) } \\
\hline Strongly disagree & $-10 \%$ & $-10 \%$ & $-9 \%$ & $-3 \%$ \\
\hline Disagree & $+3 \%$ & $+1 \%$ & $-4 \%$ & $-3 \%$ \\
\hline Neither & $+4 \%$ & $+6 \%$ & $+3 \%$ & $-4 \%$ \\
\hline Agree & $+2 \%$ & $+3 \%$ & $+8 \%$ & $+4 \%$ \\
\hline Strongly agree & $+1 \%$ & $+1 \%$ & $+2 \%$ & $+6 \%$ \\
\hline \multicolumn{5}{|c|}{ Age: $46-60$ (vs. Age: 18-30) } \\
\hline Strongly disagree & $+10 \%$ & $+9 \%$ & n.s. & n.s. \\
\hline Disagree & $-3 \%$ & n.s. & n.s. & n.s. \\
\hline Neither & $-4 \%$ & $-5 \%$ & n.s. & n.s. \\
\hline Agree & $-2 \%$ & $-2 \%$ & n.s. & n.s. \\
\hline Strongly agree & $-1 \%$ & $-1 \%$ & n.s. & n.s. \\
\hline \multicolumn{5}{|c|}{ Age: >60 (vs. Age: 18-30) } \\
\hline Strongly disagree & $+15 \%$ & $+12 \%$ & $+6 \%$ & $+2 \%$ \\
\hline Disagree & $-5 \%$ & n.s. & $+3 \%$ & $+3 \%$ \\
\hline Neither & $-6 \%$ & $-6 \%$ & $-2 \%$ & $+3 \%$ \\
\hline Agree & $-2 \%$ & $-3 \%$ & $-5 \%$ & $-3 \%$ \\
\hline Strongly agree & $-1 \%$ & $-1 \%$ & $-1 \%$ & $-4 \%$ \\
\hline \multicolumn{5}{|c|}{ No formal qualification (vs. Higher education) } \\
\hline Strongly disagree & $-14 \%$ & n.s. & n.s. & $+4 \%$ \\
\hline Disagree & $+4 \%$ & n.s. & n.s. & $+5 \%$ \\
\hline Neither & $+6 \%$ & n.s. & n.s. & $+5 \%$ \\
\hline Agree & $+2 \%$ & n.s. & n.s. & $-5 \%$ \\
\hline Strongly agree & $+1 \%$ & n.s. & n.s. & $-8 \%$ \\
\hline \multicolumn{5}{|c|}{ Trade or diploma certificate (vs. Higher education) } \\
\hline Strongly disagree & $-10 \%$ & n.s. & n.s. & $+3 \%$ \\
\hline Disagree & $+3 \%$ & n.s. & n.s. & $+4 \%$ \\
\hline Neither & $+4 \%$ & n.s. & n.s. & $+4 \%$ \\
\hline Agree & $+1 \%$ & n.s. & n.s. & $-4 \%$ \\
\hline Strongly agree & $+1 \%$ & n.s. & n.s. & $-7 \%$ \\
\hline Maori (vs. Not Maori) & & & & \\
\hline
\end{tabular}




\begin{tabular}{|c|c|c|c|c|}
\hline & \multicolumn{4}{|c|}{ Model for children aged ... } \\
\hline & $\begin{array}{c}3-5 \\
\text { years }\end{array}$ & $\begin{array}{l}6-10 \\
\text { years }\end{array}$ & $\begin{array}{l}11-14 \\
\text { years }\end{array}$ & $\begin{array}{l}15-18 \\
\text { years }\end{array}$ \\
\hline Strongly disagree & $-13 \%$ & $-10 \%$ & n.s. & n.s. \\
\hline Disagree & $+3 \%$ & n.s. & n.s. & n.s. \\
\hline Neither & $+6 \%$ & $+6 \%$ & $+1 \%$ & n.s. \\
\hline Agree & $+3 \%$ & $+3 \%$ & n.s. & n.s. \\
\hline Strongly agree & $+1 \%$ & $+1 \%$ & n.s. & n.s. \\
\hline \multicolumn{5}{|c|}{ Children in household (vs. No children in household) } \\
\hline Strongly disagree & $-6 \%$ & $-6 \%$ & $-4 \%$ & n.s. \\
\hline Disagree & $+2 \%$ & n.s. & -2 & n.s. \\
\hline Neither & $+3 \%$ & $+3 \%$ & $+1 \%$ & n.s. \\
\hline Agree & $+1 \%$ & $+2 \%$ & $+4 \%$ & n.s. \\
\hline Strongly agree & $+1 \%$ & $+1 \%$ & $+1 \%$ & n.s. \\
\hline \multicolumn{5}{|c|}{ Top income quartile (vs. Bottom income quartile) } \\
\hline Strongly disagree & $+10 \%$ & $+11 \%$ & n.s. & $+2 \%$ \\
\hline Disagree & $-3 \%$ & n.s. & n.s. & $+3 \%$ \\
\hline Neither & $-4 \%$ & $-6 \%$ & $-2 \%$ & n.s. \\
\hline Agree & n.s. & $-3 \%$ & n.s. & $-3 \%$ \\
\hline Strongly agree & n.s. & $-1 \%$ & n.s. & n.s. \\
\hline \multicolumn{5}{|c|}{ No vote or no information (vs. the Nationals) } \\
\hline Strongly disagree & $-12 \%$ & $-10 \%$ & n.s. & n.s. \\
\hline Disagree & $+4 \%$ & $+1 \%$ & n.s. & n.s. \\
\hline Neither & $+5 \%$ & $+5 \%$ & n.s. & n.s. \\
\hline Agree & $+2 \%$ & $+2 \%$ & n.s. & n.s. \\
\hline Strongly agree & $+1 \%$ & $+1 \%$ & n.s. & n.s. \\
\hline \multicolumn{5}{|c|}{ Labour Party (vs. the Nationals) } \\
\hline Strongly disagree & $-13 \%$ & $-12 \%$ & $-7 \%$ & $-2 \%$ \\
\hline Disagree & $+4 \%$ & $+1 \%$ & $-3 \%$ & $-3 \%$ \\
\hline Neither & $+5 \%$ & $+6 \%$ & $+2 \%$ & $-3 \%$ \\
\hline Agree & $+2 \%$ & $+3 \%$ & $+6 \%$ & $+3 \%$ \\
\hline Strongly agree & $+1 \%$ & $+1 \%$ & $+2 \%$ & $+5 \%$ \\
\hline \multicolumn{5}{|c|}{ Greens (vs. the Nationals) } \\
\hline Strongly disagree & n.s. & $-13 \%$ & $-11 \%$ & $-4 \%$ \\
\hline Disagree & $+3 \%$ & n.s. & $-6 \%$ & $-5 \%$ \\
\hline Neither & n.s. & $+7 \%$ & $+2 \%$ & $-6 \%$ \\
\hline Agree & n.s. & $+4 \%$ & $+11 \%$ & $+4 \%$ \\
\hline Strongly agree & n.s. & $+2 \%$ & $+3 \%$ & $+11 \%$ \\
\hline \multicolumn{5}{|c|}{ Other party (vs. the Nationals) } \\
\hline Strongly disagree & $-18 \%$ & $-22 \%$ & -9 & $-4 \%$ \\
\hline Disagree & $+4 \%$ & n.s. & n.s. & $-6 \%$ \\
\hline Neither & $+8 \%$ & $+13 \%$ & +2 & $-6 \%$ \\
\hline Agree & $+3 \%$ & $+8 \%$ & +10 & $+4 \%$ \\
\hline Strongly agree & n.s. & $+4 \%$ & n.s. & $+13 \%$ \\
\hline
\end{tabular}

Notes: Cells give the difference in the percentage (\%) of cases in a variable category predicted to fall into each of the five response options relative to the reference category, adjusting for any covariates. n.s.: non-significant. 